\title{
Assassinatos por encomenda: a sicaresca no cinema colombiano ${ }^{1}$ Professional Killers: the sicaresca in the Colombian cinema
}

Maurício de Bragança²

${ }^{1}$ Este artigo é resultado do projeto pesquisa "Fronteiras interamericanas: imagens de uma cartografía cultural em construção" financiada pelo CNPq através da bolsa MCTI/CNPQ/Universal 14/2014.

${ }^{2}$ Possui graduação em Comunicação Social com Habilitação em Cinema pela Universidade de São Paulo (1970), mestrado em Letras (Teoria Literária e Literatura Comparada) pela Universidade de São Paulo (1975), doutorado em Letras (Teoria Literária e Literatura Comparada) pela Universidade de São Paulo (1980) e doutorado em Cinema Studies - New York University (1982). Professor associado da Universidade de São Paulo. 
Resumo: Neste artigo, discutiremos o personagem do matador de aluguel a partir dos filmes La virgen de los sicarios (Barbet Schroeder, Col/Fra/Esp, 2000) e Rosario Tijeras (Emilio Maillé, Col/Mex/Esp/Bra, 2005). Centradas nos crimes relacionados ao narcotráfico que tomam conta do país, as narconarrativas reivindicam uma apropriação da realidade social, política e econômica, ao abordarem o mundo do crime decorrente do tráfico de drogas. O matador de aluguel, conhecido como sicário na América Hispânica, problematiza o esgotamento dos horizontes morais e legais ao tratar do tema da violência, abrindo a possibilidade de se pensar o mundo do crime por uma perspectiva cultural, a partir de um narcoimaginário e de políticas de reconhecimento coletivo no âmbito social.

Palavras-chave: sicaresca; Colômbia; matador de aluguel; narcotráfico.

Abstract: In this article we will discuss the character of the professional killer from the movies La virgen de los sicarios (Barbet Schroeder, Col/Fra/Esp, 2000) and Rosario Tijeras (Emilio Maillé, Col/Mex/Esp/Bra, 2005). Focused on crimes related to drug trafficking that take over the country, the narconarratives point an appropriation of the social, political and economic reality. The professional killer, known as sicario in Spanish America, points to the crisis of a moral and legal horizon, presenting the issue of violence, opening up the possibility of thinking about the world of crime by a cultural perspective, from a narco imaginary. Violence is presented in a globalized dimension of production of meanings.

Key words: sicaresca; Colombia; professional killer; narco. 


\section{O mundo do crime}

Muito presente nas narrativas do jornalismo policial, o narcotráfico também faz parte do mercado de entretenimento ao conferir matriz dramática a inúmeros produtos da indústria audiovisual. Nas últimas décadas, vimos emergir, na América Latina, uma verdadeira indústria do entretenimento relacionada às histórias do narcotráfico, ganhando espaço na cultura das mídias (BRAGANÇA, 2012) e forjando um poderoso estereótipo, de proporções internacionais, da cultura latino-americana. Através da produção de um grande número de filmes, séries televisivas e novelas, as narrativas sobre o narcotráfico desenham uma espécie de cartografia cultural do mundo do crime, das contravenções e das várias práticas em torno das ilegalidades.

Percebemos o "mundo do crime" como estratégias de representação de um conjunto de relações sociais e discursivas que produzem sentido a partir de determinados contextos historicamente estabelecidos. Nesta perspectiva, pretendemos analisar o mundo do crime e suas variáveis em suas significações culturais, para além das implicações morais, ou sob uma perspectiva ética forjada pelos mecanismos de poder e de controle constituídos pelo estado moderno. Dessa forma, não há um julgamento de valor que orienta nossas análises, mas, pelo contrário, há uma disposição em perceber as representações das práticas do crime como estratégias discursivas que buscam possibilidades de reconhecimento coletivo. Os crimes e delitos se apresentam, nestas narrativas, como uma espécie de instrumento crítico que marca uma cultura e suas fronteiras ao mesmo tempo móveis, históricas e processuais ao relacionar estado, sujeito e sociedade em permanente tensão.

Neste artigo, para pensarmos os filmes colombianos propostos, assumimos uma cartografia que desliza por experiências de outros países latino-americanos, como forma de evidenciarmos um diálogo em comum que também inclua o Brasil, historicamente apartado deste contexto simbólico latino-americano. As narrativas literárias e cinematográficas aqui abordadas são tomadas como universos próprios, com suas respectivas formulações narrativas e estratégias de linguagem e representação. A leitura dos filmes privilegiará determinadas cenas que nos ajudem a encaminhar nossa argumentação. Apesar dos filmes analisados terem origem em romances, não estamos particularmente interessados nas discussões sobre as adaptações literárias. Assim, tais textos literários e cinematográficos não serão colocados em perspectiva comparada, mas nos interessa pensar como traduzem importantes discussões capazes de desvelar um imaginário em torno das práticas simbólicas latino-americanas nas quais percebemos as contradições de uma modernidade que tensiona os paradigmas 
da modernidade ocidental. Assim como aponta a antropóloga mexicana Rossana Reguillo (2009), acreditamos que

\begin{abstract}
não era possível entender o que está ocorrendo com o narcotráfico a partir da dicotomia moderna: legalidade/ ilegalidade, mas teria que incorporar um terceiro campo analítico, a "paralegalidade", entendida como aquela zona indefinida que abre as violências e de onde o narco desdobra todo o seu poder, que não é apenas um poder de verdade, não é apenas um poder de morte, mas que é fundamentalmente um poder fundacional-cultural, isto é, capaz de gerar seus próprios códigos, suas próprias regras e sua própria ordem paralela.
\end{abstract}

Seguindo esta perspectiva, avaliamos que a linguagem do narco estabelece parâmetros de comunicação com a sociedade que dialogam com um imaginário coletivo em torno da violência formado pelas expressões culturais das práticas cotidianas. Dessa forma, essa narcolinguagem se apropria de um capital simbólico capaz de estabelecer efetivas relações de reconhecimento e adesões coletivas.

\section{O matador de aluguel}

Neste artigo, investigaremos um importante personagem desse imaginário da violência latino-americana: o matador de aluguel, protagonista ativo nas execuções por encomenda, os chamados “crimes de pistolagem”. Este personagem faz parte das tradicionais relações de poder na América Latina, sendo uma peça imprescindível na articulação de um conjunto de códigos e valores sociais que conformam o "sistema de pistolagem" (BARREIRA, 2014). O trabalho do matador de aluguel é fundamental na organização econômica, política e social da estrutura agrária latino-americana, atuando de forma violenta nas resoluções de conflitos e disputas no campo em favor da manutenção do latifúndio e da preservação das práticas coronelistas ${ }^{3}$, tanto no Brasil, como nos demais países do subcontinente. Sua presença na produção cultural brasileira, por exemplo, é antiga, atravessando a literatura, o cinema e a televisão. Do Riobaldo de Guimarães Rosa e suas lembranças do tempo de jagunçada ao Dalvino da Tocaia Grande de Jorge Amado, passando por um sem número de histórias de cordel até o emblemático Antonio das Mortes, de Glauber Rocha, ou, na TV, o Zeca Diabo de Dias Gomes: os matadores de origem rural sempre estiveram a postos para garantirem as histórias que fundam uma tradição em torno das relações de poder num Brasil arcaico e oligárquico. No cinema brasileiro após 1990, eles estiveram

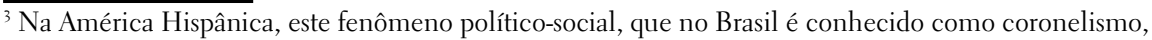
recebe o nome de caciquismo.
} 
frequentemente nas telas. O diretor Beto Brant se ocupou deles em Os matadores, de 1997, e O invasor, de 2002. Podemos citar ainda O homem do ano, de José Henrique Fonseca (2003) e Cabeça a prêmio, de Marco Ricca (2009), dentre muitos outros.

No processo de modernização levado a cabo na América Latina, os paradoxos que envolvem o moderno e o arcaico estabelecem as matrizes para um desenvolvimento periférico, configurando mudanças também na etnografia deste profissional. Os matadores de aluguel acabaram se dispersando espacialmente e vindo a ocupar também as periferias das grandes cidades, dando ao pistoleiro alguma autonomia de atuação desvinculada do abrigo de um patrão ou protetor. Deixam de ser, portanto, nas últimas décadas do século XX, um fenômeno eminentemente rural, passando a ocupar também a paisagem das grandes cidades, nas quais os matadores ganham um maior anonimato. Nos países latino-americanos da década de 1990, momento em que o narcotráfico se fortalece no interior de uma ordem neoliberal - os pistoleiros urbanos ganham ares de freelancer ${ }^{4}$. Esse pistoleiro autônomo passa a coexistir com o já tradicional enraizamento do matador ligado ao grande proprietário ou com as novas formas de pertencimento a um sistema de pistolagem agenciado pelos negócios do narcotráfico. Segundo Cesar Barreira, sociólogo dedicado às pesquisas sobre o sistema de pistolagem no Brasil, estes crimes possuem aspectos de execução peculiares:

São homicídios cometidos utilizando-se da prática da emboscada, na qual a vítima é pega de surpresa, ocorrendo vários disparos. Os tiros são, geralmente, na cabeça, e o assassinato ocorre sem a precedềncia da discussão. São ações que se desenrolam, em geral, em lugares públicos. O autor material do crime não faz parte da rede social da vítima. Finalmente, a ação fatal é praticada empregando a motocicleta como veículo, havendo a participação de duas pessoas: do garupeiro e do condutor (BARREIRA, 2014, p. 314).

A ação descrita acima, encenada várias vezes no cinema e na TV, constituise numa espécie de clichê das narrativas de pistolagem. Esta mise-en-scéne combina elementos dos relatos policiais das páginas dos jornais com a ficção, organizando um conjunto de imagens em torno da ação do pistoleiro que, frequentemente, protagoniza enfrentamentos ligados às disputas urbanas relacionadas ao mundo do crime. No ambiente das cidades contemporâneas, a violência ganha um aspecto difuso e confere matriz narrativa às inúmeras representações do espaço urbano no

\footnotetext{
${ }^{4}$ É interessante que o termo freelancer, literalmente "lanceiro livre" em inglês, tem origem nos cavaleiros medievais mercenários que vendiam seu trabalho de guerrear aos nobres que melhor lhe pagassem. $\mathrm{O}$ termo está descrito no romance Ivanhoé, de Walter Scott, de 1820.
} 
cinema latino-americano.

Na Colômbia, a violência promovida pelo narcotráfico a partir dos anos 1980 ganhou repercussão quase imediata no cenário político, social e também cultural do país, tendo à frente a figura de Pablo Escobar, o grande protagonista das matérias jornalísticas que marcaram a vida política colombiana no final daquela década ${ }^{5}$. A cidade de Medellín seria um dos principais polos desta narcocartografia latino-americana, que incluiria também a cidade de Cali, assim como as mexicanas Culiacán, Tijuana e Ciudad Juárez, além do Rio de Janeiro, no Brasil, dentre outras. Este mapa das drogas iria fomentar várias narrativas ficcionais, criando um forte imaginário internacional relacionado a uma geografia marcada por extrema violência, toneladas de cocaína, armas de guerra, o narcoterrorismo e seus macabros rituais de execução, e a ação cotidiana do trabalho dos matadores de aluguel.

\section{Os matadores na literatura colombiana: la sicaresca}

Nos anos 1990, o mercado literário colombiano viu surgir uma série de romances que traziam como protagonista o personagem do pistoleiro, conhecido no ambiente hispânico como sicario. O êxito deste repertório é tão grande no mercado editorial do país que este fenômeno acabou sendo conhecido como la sicaresca. Trazendo histórias em torno destes assassinos por encomenda, as narrativas da sicaresca se apropriavam da realidade social, política e econômica do país, reafirmando o papel central destes matadores no cotidiano das cidades. Medellín, neste cenário, ganhava uma destacada importância, com todas as contradições sociais que acentuavam os cinturões de miséria nas margens do perímetro urbano, local de onde vinham os profissionais da morte.

Medellín toma forma dependendo da posição geográfica do sujeito que a habita, e esta condição é o que impede de singularizá-la a partir de uma única e determinada experiência coletiva. É isto o que obriga a falar, necessariamente, de duas cidades, donas cada uma de seus próprios sistemas de sociabilidade, atitudes e expressões culturais particulares que as definem (LANDER, 2007, p. 166).

As diferentes zonas da cidade assumem um papel fundamental não apenas

\footnotetext{
Ainda hoje a imagem de Pablo Escobar é responsável pelo êxito de várias produções da indústria do entretenimento, alavancando produtos como a série de TV Escobar, el patrón del mal, produzida e exibida pela produtora colombiana Caracol Televisión, em 2012. O enorme sucesso da série deu início a uma verdadeira "escobarmania" recentemente, com produções como a cinebiografia de 2014 estrelada por Benício del Toro, Escobar: Paradise Lost, dirigida por Andrea Di Stefano, ou ainda a série brasileira dirigida por José Padilha, Narcos, que traz Wagner Moura no papel do polêmico narcotraficante.
} 
como convenção distrital de um mapa geográfico, mas sobretudo no enquadramento do urbano como um espaço de desordenamento da cultura, inserido no âmbito da produção e circulação dos discursos numa esfera midiática mais ampla. No bestseller de Fernando Vallejo publicado originalmente em 1994, A virgem dos sicários, as diferenças sociais entre as várias zonas da cidade definem um mapa da violência que organiza a atuação desses profissionais, oriundos das comunas, região de miséria situada nas colinas que cercam a cidade de Medellín. Na descrição dessas regiões pela narrativa de Vallejo, percebe-se que as comunas são um território de exclusão social que se assemelha a outros espaços marginais localizados na Colômbia, México, Brasil, ou mesmo Índia ou Angola, criando uma periferia globalizada que tem uma forte presença nos circuitos midiáticos ${ }^{6}$.

Ribanceiras, lixões, barrancos, vales, encostas, isso são as comunas. E o labirinto de ruas cegas com construções caóticas, prova viva de como nasceram: como bairros "de invasão" ou "piratas", sem planejamento urbano, as casas construídas às pressas em terrenos roubados e defendidos com sangue pelos que roubaram para que ninguém as fosse roubar (VALLEJO, 2006, p. 55 ).

Organicamente vinculados a este espaço de segregação, os sicarios exercem seu ofício de morte no qual associam os bens de consumo (as roupas de marca, a hierarquia letal das armas na qual a submetralhadora Mini Uzi é objeto de fetiche, o apreço pelas motos envenenadas) a rituais religiosos ressignificados pela ética do narcotráfico. Dessa forma, acabam por impor um estilo de vida e uma estética ligada à ostentação e a um empoderamento pelo mercado de consumo, aliado a padrões presentes na cultura popular e na indústria cultural.

É importante ressaltar que o assassino de aluguel não é uma representação plana ou superficial que se reitera como um padrão neste gênero literário. Ora se apresenta como um personagem em deslocamento, buscando a melhor maneira de superar a precária situação familiar (Sangre Ajena, de Arturo Alape, 2000), ora como herdeiro dos negócios da família, mantendo as tradições internas ao mundo do crime

\footnotetext{
$\overline{{ }^{6} \text { Não podemos deixar }}$ de mencionar como a arquitetura desses espaços foi representada no cinema a partir de uma ideia de "periferia global". Esses territórios são construídos de forma labiríntica, através de ruelas, passagens e corredores extremamente estreitos, sem possibilidade de saída para além desse circuito endógeno da miséria. É bastante comum que essa arquitetura inspire cenas de fugas e perseguições frenéticas a partir das quais a montagem encadeia uma sucessão de planos muito curtos, organizados de forma eletrizante. Este cenário geralmente é constituído pelo entulhamento: montanhas de saco de lixo, escombros e acúmulo de objetos de cena. Essa descrição está presente na cena inicial da favela de Cidade de Deus (Fernando Meirelles e Katia Lund, Brasil, 2002) e de Quem quer ser um milionário? (Danny Boyle e Loveleen Tandan, Inglaterra/EUA, 2008), além do mercado popular onde se passa o filme 7 caixas (Juan Carlos Maneglia e Tana Schembori, Paraguai/Espanha, 2012).
} 
(Morir con papá, de Óscar Collazos, 1997), ou ainda como parte de uma cadeia de consumo instaurada na sociedade colombiana pelo tráfico de drogas (La Virgen de los Sicarios, de Fernando Vallejo, 1994).

O narcotráfico surgia, então, como argumento estruturante da narrativa literária colombiana ao final do século $\mathrm{XX}$, constituindo as bases de um repertório que, ao reordenar as alegorias do realismo mágico pelo absurdo das situações de extrema violência e pela ostentação do poder, apresentava um relato que, segundo a pesquisadora Margarita Jácome (2009, p. 23), "subverte vários elementos narrativos dos gêneros testemunho e documental" ". Nesta perspectiva, o narcotráfico detonou, na Colômbia, uma verdadeira revolução cultural (ÁLVAREZ GARDEAZABAL, 1995), capaz de incomodar a sociedade burguesa, a sociedade letrada e a sociedade política (RINCÓN, 2013).

Neste repertório literário, dois romances se destacam, repercutindo estrondosamente no circuito midiático colombiano do final do século, ajudando a construir a mitologia em torno do personagem: La Virgen de los Sicarios, de Fernando Vallejo (1994) e Rosario Tijeras, de Jorge Franco (1999), ambos adaptados ao cinema. O texto de Vallejo foi levado às telas por Barbet Schroeder, numa coprodução Colômbia, França e Espanha em 2000, e Rosario Tijeras por Emilio Maillé, numa coprodução Colômbia, México, Espanha e Brasil em 2005. A história da sexy pistoleira de Medellín deu origem ainda a uma telenovela colombiana intitulada Rosario Tijeras - amar é mais difícil que matar, com enorme audiência no país e exportada para quase toda a América Latina e Estados Unidos. No Brasil, a telenovela estreou no início de 2014, na Rede Bandeirantes, e hoje está disponível no serviço de streaming Netflix.

Aqui, interessa-nos pensar, no que toca às obras A virgem dos sicários e Rosario Tijeras (os romances e os filmes), de que maneira a figura do sicario problematiza o esgotamento dos horizontes morais e legais ao tratar do tema da violência, abrindo a possibilidade de se pensar o mundo do crime, dos delitos e das contravenções - sobretudo ligado ao universo do narcotráfico - por uma perspectiva cultural que aponta os paradoxos da modernidade latino-americana, revelando um narcoimaginário que se manifesta nas políticas de reconhecimento coletivo no âmbito social (BRAGANÇA, 2012). Para isso, tomaremos como questão aquilo que Omar Rincón (2009) denomina uma narco.estética da sicaresca, conjugada a uma

\footnotetext{
${ }^{7}$ Estas narrativas inspiraram também um repertório cinematográfico mexicano que ganha corpo na década de 1970, conhecido como narcocine. Este subgênero dos filmes de ação geralmente tirava seus enredos das letras dos narcocorridos (estilo de canção nortenha que traz como temática o mundo do narcotráfico) e tinha um forte apelo popular, sobretudo junto ao público da fronteira norte do México. Para uma maior discussão sobre o narcocine mexicano, consultar BRAGANÇA (2013).
} 
ética própria deste universo no qual se destaca uma nova moral religiosa. Para o autor, a narco.estética está ligada a um estilo de vida de matriz popular relacionado a um ideal de ostentação: "Está feita de exagero, formada pelo que é grande, ruidoso, estridente; uma estética de objetos e arquitetura, escapulário e virgem; música a toda hora e a todo volume, narco.toyota prateada, exibicionismo do dinheiro. Em síntese, a obstinação da abundância, o grande volume, a ostentação dos objetos" (RINCÓN, 2009, p. 151).

\section{Narcotráfico e religião}

As relações entre o mundo do crime e a religião constituem-se práticas recorrentes nas manifestações populares latino-americanas. No México, o culto à Santa Morte e a Jesus Malverde vincula a fé religiosa ao exercício das ilegalidades. Essas manifestações sincréticas, que combinam elementos relacionados às tradições católicas com permanências de ritos pré-hispânicos, cresceram muito desde os anos 1980, tendo saído da clandestinidade e tornado públicos seus rituais há menos de vinte anos, ainda que muitos devotos exerçam sua fé no espaço da intimidade por temor a perseguições, como nos aponta Andrew Chesnut (2011, p. 206): "Por conta de sua associação com o crime organizado, especialmente com traficantes de droga e sequestradores, além da condenação por parte das igrejas católica e protestantes, crentes mais abastados tendem a manter sua devoção no âmbito privado".

Tanto a Santa Morte quanto Jesus Malverde estão relacionados ao mundo do crime, dos delitos e das contravenções, tendo uma enorme popularidade entre os presidiários mexicanos e latinos nos Estados Unidos. Na vela votiva da Santa Morte costuma-se encontrar a seguinte inscrição: "lei, fique longe!". Jesus Malverde é tradicionalmente cultuado por todos aqueles que se encontram à margem da lei, os excluídos que precisam de proteção para contornar problemas penais, os ilegais de um modo geral, e sobretudo por todos aqueles que pretendem migrar de forma clandestina para os Estados Unidos. A devoção de chefes dos cartéis de narcotráfico mexicano ao santo popular é já conhecida, e segundo o pesquisador Elijah Wald (2001, p. 65), que se refere a Malverde como um "narcosanto":

Hoje em dia surge sua imagem por todo o mundo das drogas no noroeste. Quando a polícia ou os soldados chegam aos cultivos de maconha ou de papoulas, sempre encontram capelas de Malverde e medalhas do santo penduradas dos paus à beira dos campos, e muitas "mulas" nem pensariam em atravessar a fronteira sem sua medalha de Malverde pendurada no pescoço. 
As relações entre o narcotráfico e a religião se desenvolvem em diversos aspectos da sociedade mexicana. Segundo Juan Carlos Ramírez-Pimienta (2011), uma destas articulações se esboça nas doações de dinheiro do tráfico às instituições religiosas, as chamadas narco-esmolas. No filme O crime do padre Amaro, dirigido por Carlos Carrera em 2002, vemos um padre que aceita a doação de um líder do tráfico local, dinheiro que ajuda a construir um moderno hospital para a comunidade. Esse tipo de prática é ainda recorrente no contexto da beneficência mexicana, revelando as aproximações entre o crime e a religião, onde a doação de dinheiro às igrejas parece possibilitar uma purificação de sua origem escusa. É ainda Ramírez-Pimienta (2011, p. 184) quem nos declara:

Em setembro de 1997 o sacerdote Raúl Soto, padre da Basílica de Guadalupe na Cidade do México, disse em sua homilia que mais pessoas deveriam seguir o exemplo dos narcotraficantes Rafael Caro Quintero e Amado Carrillo, que haviam feito doações milionárias à Igreja. Apesar das múltiplas críticas vindas de muitos setores sociais uma primeira defesa da Igreja Católica enfatizou, através de Alberto Athié, secretário executivo da Comissão Pastoral Social do Episcopado, que não correspondia a eles andar fiscalizando seus doadores. Esta posição da Igreja foi reiterada através dos anos por outros representantes da mesma. Em abril de 2008 o bispo de Texcoco, México, Carlos Aguiar Retes, voltou a se referir às narco- esmolas em termos parecidos aos de Soto, exaltando a generosidade de alguns narcotraficantes e fazendo uma validação total destes como atores sociais, atores que inclusive cumprem algumas das funções do Estado mexicano já que: "fazem obras muito significativas para a comunidade: põem luz e se encarregam de financiar a construção de estradas. Também constroem Igrejas e capelas. Isto ocorre em algumas cidades muito distantes da serra, onde o governo não tem recursos para atuar".

Os títulos dos dois romances citados já apontam para o universo católico profanado. A Virgem dos Sicarios nos remete, até de forma cínica, à fé e ao culto religioso na sociabilidade dos matadores colombianos. Os personagens perambulam pelas ruas de Medellín entrando e saindo de igrejas, buscando proteção no exercício da profissão e momentos de prazer no ambiente religioso. As igrejas no romance convertem-se em lugares onde se pede ajuda no crime, onde se usa droga e se consegue rapazes para o sexo: "Deus, que tudo vê, ouve e entende, há de saber que em sua basílica maior, nossa Catedral Metropolitana, nos bancos de trás, os rapazes e travestis se vendem, armas e drogas são negociadas, e se fuma maconha" (VALLEJO, 2006, p. 50). A gratuidade dos assassinatos que o jovem Alexis comete 
na sua caminhada pela cidade não é incompatível com uma ética religiosa segundo a qual os crimes se combinam com rituais de proteção católica.

As balas rezadas se preparam assim: ponha seis balas numa panela previamente aquecida até o vermelho vivo numa grelha elétrica. Borrife em seguida a água benta obtida na pia de uma igreja, ou fornecida, sob garantia, pela paróquia de São Judas Tadeu (...). A água, benta ou não, evapora por causa do calor violento, e, enquanto isso, vá rezando com fé de carvoeiro aquilo que reza: "Pela graça de são Judas Tadeu (...), que estas balas assim consagradas atinjam o alvo sem falhar e que o defunto não sofra. Amém." (VALLEJO, 2006, p. 59).

Esta ética do sicariato, associando de forma cínica a prevenção divina e a eficiência na execução dos trabalhos, onde símbolos religiosos fornecem as senhas para os homicídios, ajuda-nos a pensar também em um novo regime de ambivalência em torno dos limites da legalidade. O padrão ético forjado pela modernidade não dá conta de entender um novo sistema de operacionalização da economia, no qual os limites entre o legal e o ilegal tornam-se menos evidentes e precisos. Numa economia globalizada, marcada pelo circuito transnacional de circulação de bens, mercadorias e pessoas, as relações entre o formal e o informal, o legal e o ilegal tornam-se ambivalentes. As dinâmicas entre o estado, a economia e a sociedade são redefinidas por essa perspectiva globalizante, na qual também se opera uma generalização, num espectro econômico mais ampliado, das práticas ilícitas e delituosas. Segundo Vera da Silva Telles (2010), é nesses termos que as economias vêm se estruturando: "essa indistinção entre o legal e o ilegal, o lícito e o ilícito, o oficial e o paralelo já compõe o estado de coisas, na justaposição de redes (políticas, econômicas, nacionais e transnacionais) e as atividades ilícitas" (2010, p. 161). O mundo urbano se redefine pelas formas contemporâneas de produção e circulação de riquezas, ativando diversos circuitos de economia informal que se acomodam em práticas informais e ilícitas.

Pensando o funcionamento do narcotráfico especificamente, as ilegalidades e todas as práticas de crimes da ordem do cotidiano se processam na articulação com as ilegalidades em âmbito maior, na qual persiste uma ligação entre uma economia clandestina e uma economia legal. Como nos mostra Thiago Rodrigues (2004), o dinheiro proveniente do tráfico não permanece no circuito ilegal, mas transita pelos fluxos financeiros internacionais onde a origem ilegal dos narcodólares é subtraída através de depósitos em paraísos fiscais, para que possam ser reaplicados em outros negócios, clandestinos ou não. Desta forma, podemos ver que tanto o mercado financeiro internacional quanto os discursos religiosos proferidos dos púlpitos da igreja católica mexicana estão comprometidos com formas de legalização e purificação da 
origem criminosa do capital proveniente do narcotráfico.

Assim, a sobrevivência de sujeitos como os sicarios, e de suas práticas criminosas cotidianas, faz parte de uma rede de funcionamento que coloca em xeque as dicotomias em torno da legalidade/ilegalidade, ou ainda, relativiza a ideia de "mundo das margens" como algo que está fora dos procedimentos próprios ao "mundo oficial", instaurando uma ética própria, inventando novas formas de vida e redefinindo o espaço e o tempo da experiência urbana.

\section{As narrativas: A virgem dos sicários e Rosário Tijeras}

N’A Virgem dos Sicários, romance e filme, a cidade de Medellín se apresenta em função das estratégias de acesso aos bens de consumo. Os sicários vindos de classes sociais desprivilegiadas oferecem-se como amantes aos homens mais ricos, aqueles que garantirão sua sobrevivência por meio do consumo de bens materiais. As diversas Medellín se forjam no encontro entre estes universos distintos. A primeira cena do filme narra a visita de Fernando a um velho amigo. Fernando é um velho escritor e linguista homossexual que, depois de 30 anos fora do país, retorna à sua cidade natal. A casa de seu amigo é decorada com signos de uma classe alta e aristocrática, com espelhos de rebuscadas molduras douradas, móveis clássicos e muitas estatuetas de mármore, reproduzindo um clichê de um ambiente de suntuosidade. Ali, vários homens mais velhos se encontram com rapazes bem jovens, de evidente condição social inferior. O lugar é repleto de relógios, de variados tamanhos,

um quartinho no fundo do apartamento que, se me permitem, descrevo de passagem, depressa, a caminho do quarto, sem profusões balzaquianas: profuso como Balzac nunca sonhou, de móveis e relógios velhos; relógios, relógios e relógios velhos e para lá de velhos, de parede, de mesa, às dezenas, às centenas, todos parados em horas diferentes, zombando da eternidade, negando o tempo (VALLEJO, 2006, p. 10).

No quartinho, também descrito na passagem do romance recortada acima, Fernando e o jovem Alexis se apresentam, e ao se despirem vemos os elementos que denotam a identidade do sicario: os escapulários no pescoço para proteção, as cicatrizes no corpo, a arma que cai ao chão e a que ele, carinhosamente, chama de ferro. Ao ver o revólver, Fernando indaga ao jovem porque leva a arma, ao que ele contesta dizendo que há vários namorados que o querem matar. Diante da estranheza da resposta, o pistoleiro completa: "São namorados com ódio". Esse paradoxo parece marcar a complexidade das relações amorosas e o próprio funcionamento 
da sociedade retratada pelo filme. A ambiguidade é trabalhada também no cenário, onde se veem vários relógios de pêndulo nas paredes, cada qual marcando uma hora diferente.

Se os vários relógios destoantes parecem apostar na permanência, debochando do tempo, acreditando numa suposta eternidade e solidez das tradições e da alta cultura, esta é desbancada pela fugacidade da vida anunciada pela presença dos sicarios, jovens sem futuro, dispostos a morrer antes dos $20 \mathrm{em}$ troca do consumo da frivolidade da cultura de massa. A conversa entre Fernando e o jovem Alexis revela a impossibilidade deste diálogo e o distanciamento entre as duas cidades. Na cena da sala dos relógios, o rapaz deixa o velho intelectual a par das mudanças ocorridas em Medellín, que agora ganha uma nova identidade com as práticas da violência, uma cidade rebatizada Metralhadora, na fala do matador. No confronto entre essas duas cidades, Fernando sente saudade da Medellín de sua infância. Para Alexis será impossível sentir qualquer saudade, simplesmente porque não terá vida suficiente para isso. Para o sicario, a religião funciona como uma espécie de estratégia usada apenas para barganhar um pouco mais de tempo, o suficiente para desfrutar um par de tênis novo, uma boa noitada e a velocidade de uma moto envenenada. A boa pontaria garante $\mathrm{o}$ acesso a esses prazeres.

Em outra cena, no seu apartamento de cobertura, Fernando também está com Alexis. Cansado de ouvir em altíssimo volume o rock pesado de que o rapaz gostava, o escritor lhe propõe apreciar "a boa música": ao som de Maria Callas, os dois vão para a parte externa do apartamento apreciar os fogos de artifício que colorem o céu de Medellín, anunciando o êxito do envio de um grande carregamento de cocaína para os Estados Unidos. A cena se converte numa experiência estética do sublime, que se constrói pelas duas perspectivas: a voz magistral da soprano é a trilha sonora para a explosão de cores que cobrem o céu da cidade, trazendo êxtase para os rostos de Fernando e Alexis. Mais uma vez, a cena é carregada de ambiguidade, pontuando os paradoxos que realçam as duas faces da cidade de Medellín. O som do espocar dos fogos de artifício complementa os acordes da ária Una Voce Poco Fa d'O Barbeiro de Sevilha, de Rossini, repercutindo novos sentidos no canto lírico de Maria Callas.

Depois da morte de Alexis numa emboscada, Fernando acaba se envolvendo com outro jovem matador, Wílmar, sem saber que este era o assassino do seu primeiro amante. O professor continua provendo a vida destes rapazes: os pares de tênis, o aparelho de som, a geladeira que solta cubinhos de gelo como presente para a mãe do pistoleiro. É no consumo de bens que os sentidos da vida se materializam. Ao fim 
do filme, a câmera percorrerá, acompanhando o olhar de Fernando, o cadáver de Wílmar sobre uma mesa no Instituto Médico Legal. Sobre o corpo frio do rapaz, o par de tênis Reebock sobreviverá, ainda novo, àquele que, junto a diversos outros corpos de jovens rapazes na mesma sala, repercute o real, incrementado pelas estatísticas sobre a violência na Colômbia.

Rosario Tijeras também traz no título uma ambiguidade do sicariato, no paradoxo que vincula a procedência católica do primeiro nome à tesoura utilizada para capar, aos 13 anos, um daqueles que a molestara sexualmente. $\mathrm{O}$ instrumento de corte e costura, relacionado ao universo feminino tradicional, é aqui tomado como arma de transgressão na nova postura social desta mulher. A religião é profanada pela recorrência de uma nova ética, que foge do estado de direito e reinventa outras formas de acesso à cidadania e ao mundo dos bens de consumo, no uso do instrumento como estratégia para tal. O romance inicia com a Oração ao Santo Juiz:

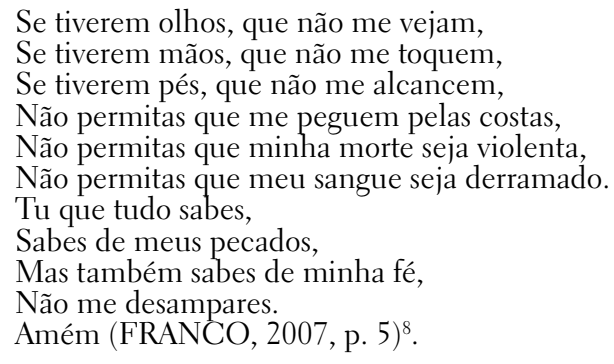

O filme de Emilio Maillé abre, ainda nos créditos, com uma cena em que uma mulher beija sensualmente um homem numa boate. São planos em câmera lenta, de close-up, de partes do corpo desta mulher: sua boca, sua mão, sua cintura enlaçada pelos braços do parceiro, seus sapatos de couro de cobra, de salto fino, diante da bota do homem que a acompanha, ornamentada com uma suástica. Finalmente o beijo, entrecortado pelo plano em que o homem desliza sua mão por dentro da saia dessa mulher. A tela transforma-se numa cartela vermelha, enquanto ouvimos o ruído seco de um tiro. A partir daí, o vermelho que parece simular sangue escorrendo ganha a forma das ruas da cidade, numa panorâmica aérea que nos faz sobrevoar a paisagem noturna, as ruas repletas de carro, faróis, luzes. O filtro vermelho desta cena dá lugar a uma imagem mais realista, onde se insere o título do filme e o nome da personagem principal: Rosario Tijeras. A música ainda é a mesma da boate, que entra em fade out para deixar crescer o som da cidade, buzinas, movimento de carros, uma sirene de ambulância. No plano, a legenda: Colômbia, Medellín, 1989,

\footnotetext{
${ }^{8}$ Uma versão dessa oração também está presente na abertura da telenovela, funcionando como uma espécie de epígrafe na produção televisiva.
} 
fazendo-nos compreender que a cidade é coprotagonista da trama.

A moça, uma sensual pistoleira que costuma deixar que suas vítimas desfrutem do seu beijo antes de serem mortas, assume o exercício da profissão com irredutível frieza, também amparada nas práticas religiosas que transformam o ato de matar numa vivência do sublime9. Em uma cena, Rosario vai visitar um antigo patrão, homem rico, de consumo refinado. Este a recebe ouvindo um hino religioso do século XIII, Stabat Mater Dolorosa, que narra a dor e o sofrimento de Maria diante do filho morto ainda pregado na cruz. Antes da chegada da pistoleira, o homem toma uísque enquanto folheia um exemplar ilustrado d'A Divina Comédia, observando as imagens dantescas do Inferno. Num rápido movimento de sedução, Rosario troca carícias com ele, enquanto lhe diz o quanto é grata por sua proteção. Beija-o ao mesmo tempo em que saca a arma da bota e o mata. Um estampido seco, fatal, o corpo no chão. Guarda a arma na cintura enquanto os últimos acordes da música anunciam o amém definitivo.

O filme é repleto destas referências religiosas, que acompanham as práticas profissionais da morte. A cidade de Medellín é filmada em seu cenário sinuoso, em suas comunidades pobres que sobem pelas montanhas em direção às nuvens, num encontro implacável entre o céu e o inferno. Aliás, este contraste entre céu e inferno pontua a narrativa, numa desorientação moral que estabelece essa nova ética do sicariato. Rosario Tijeras é uma personagem complexa, revela uma nova postura da mulher contemporânea, e rompe com a ordem da violência tradicional que a define como vítima da agressividade masculina. Aqui, é ela quem mata os homens, que subverte as estatísticas oficiais do feminicídio, e enfrenta com a arma engatilhada um imaginário de nação. Como canta o famoso star colombiano Juanes na música dedicada a ela, presente na trilha sonora da película: "Era Rosario Tijeras, a da pistola, espelhinho e batom na sua carteira sempre cheia de vício, sexo, balas, prazer e dor, a das mil e uma vidas".

\section{Conclusão}

Numa breve conclusão, vimos que este personagem, de larga tradição na nossa cultura, tem ganhado novos contornos se relacionado aos estudos de narco que vêm crescendo na abordagem dos estudos culturais latino-americanos nas últimas décadas. O sicario nos ajuda a pensar como a violência tem se convertido numa forma

\footnotetext{
${ }^{9}$ Podemos lembrar o clássico de Thomas De Quincey, Do assassinato como uma das belas artes, texto que, surgido na primeira metade do século XIX, apresenta uma espécie de culto estetizado do ato de matar.
} 
de produzir sentido dentro da indústria do entretenimento, na qual a cultura popular e os códigos das subculturas urbanas ganham feições particulares, com especial destaque para os novos modelos de relação com a tradição religiosa católica e para as formas de acesso aos bens de consumo. Assim, nosso objetivo foi pensar as estratégias de representação dos crimes de narcotráfico no mercado editorial e cinematográfico como uma possibilidade de entender as políticas de reconhecimento coletivo que estão implicadas em processos de significação responsáveis pela constituição de novos imaginários sobre o continente.

A leitura cultural das práticas relacionadas ao narcotráfico e ao mundo do crime, que oferece suporte para pensarmos políticas identitárias de subgrupos urbanos, tem sido absolutamente negligenciada pelos poderes públicos, que se recusam a perceber que esses discursos constroem redes de sociabilidade e forjam práticas sociais que garantem fortes laços de identificação coletiva. É sob esta perspectiva que vemos crescer atualmente, no interior dos estudos culturais latinoamericanos, um campo de estudos interdisciplinar focado nas estratégias discursivas relacionadas aos textos culturais sobre o narcotráfico, ao qual nos filiamos. Para além do local pitoresco que este tema reserva ao continente num âmbito internacional, é necessário enfrentarmos os clichês como forma de refletirmos de que maneira o narcotráfico hoje garante um registro importante nas tensões históricas de nossa modernidade periférica.

\section{Referências Bibliográficas}

ÁLVAREZ GARDEAZABAL, G. La cultura del narcotráfico. Debates de número, ago/sep/oct.1995. Disponível em <http://www.mamacoca.org/docs_de_base/La_ Representacion_Social_del_narcotrafico/RevistaNumero_CulturayNarcotrafico_ sep_oct_1995_AllvarezĞardeazabal.pdf> Acesso em 03 out. 2014.

BARREIRA, C. "Crimes de pistolagem e de mando". In. LIMA, Renato Sergio; RATTON, José Luiz; AZEVEDO, Rodrigo (orgs.). Crime, polícia e justiça no Brasil. São Paulo: Contexto, 2014.

BRAGANÇA, M. de. "A narcocultura na mídia: notas sobre um narcoimaginário latino-americano". Significação: Revista de Cultura Audiovisual, v. 37, 2012, p. $93-$ 109.

"Lola, la trailera: coreografias de um corpo feminino no narcocine mexicano". In: BRAGANÇA, M.; TEDESCO, M. C. (Org.). Corpos em projeção: gênero e sexualidade no cinema latino-americano. Rio de Janeiro: 7Letras, 2013.

CHESNUT, R. A. "Santa Morte, a santa esquelética no México e nos Estados Unidos". História: Questões \& Debates, Curitiba, n. 55, jul/dez, 2011, p. 195-217. 
FRANCO, J. Rosario Tijeras. Rio de Janeiro: Objetiva, 2007.

JÁCOME, M. La novela sicaresca. Testimonio, sensacionalismo y ficción. Medellín: Fondo Editorial EAFIT, 2009.

LANDER, M. F. "La voz impenitente de la 'sicaresca" colombiana. Revista Iberoamericana, vol. LXXIII, núm. 218, enero-marzo 2007, p. 165-177.

RAMÍREZ-PIMIENTA, J. C. "El narcocorrido religioso: usos y abusos de un género". Studies in Latin American Popular Culture. XXIX, 201 1, p. 184-201.

REGUILLO, R. "El lenguaje de los narcos". In: SEMINARIO NARCOTRÁFICO Y VIOLENCIA EN CIUDADES DE AMÉRICA LATINA: retos para un nuevo periodismo, 2009, México. Anais eletrônicos. México: FNPI, 2009. Disponível em $<$ http://cosecharoja.fnpi.org/wp-content/uploads/2010/09/Seminario_Narco.pdf>. Acesso em 15 ago. 2011.

RINCÓN, O. "Narco.estética y narco.cultura en Narco.lombia”. Nueva Sociedad, n. 222, Julio-agosto de 2009.

" "Todos temos um pouco do tráfico dentro de nós: um ensaio sobre o narcotráfico/cultura/novela como porta de entrada para a modernidade". São Paulo: MATRIZes, jul/dez 2013.

RODRIGUES, T. "Drogas e liberação: enunciadores insuportáveis". Verve (PUCSP), São Paulo, v. 06, n.01, 2004, p. 129-156.

TELLES, V. da S. A cidade nas fronteiras do legal e ilegal. Belo Horizonte: Argvmentvm, 2010.

VALLEJO, F. A virgem dos sicários. São Paulo: Cia das Letras, 2006.

WALD, E. Narcocorrido: un viaje al mundo de la música de las drogas, armas y guerrilleros. Harper Collins: New York, 2001.

\section{Referências filmográficas}

CABEÇA a prêmio. Marco Ricca, Brasil, 2009.

O CRIME do padre Amaro. Carlos Carrera, Mex/Esp/Arg/Fra, 2002.

O HOMEM do ano. José Henrique Fonseca, Brasil, 2003.

O INVASOR. Beto Brant, Brasil, 2002.

OS MATADORES. Beto Brant, Brasil, 1997.

ROSARIO Tijeras. Emilio Maillé, Col/Mex/Esp/Bra, 2005.

LA VIRGEN de los sicarios. Barbet Schroeder, Col/Fra/Esp, 2000.

submetido em: 02 julho 2015 | aprovado em: 19102015. 